\title{
Evaluative Language of Male and Female Film Critics in Atomic Blonde Movie Reviews: An Appraisal Study with Gendered Perspective
}

\author{
Bima Iqbal Khadafi ${ }^{1}$, Riyadi Santosa ${ }^{2}$ \\ \{bimaiqbalk@gmail.com ${ }^{1}$, riyadisantosa@staff.uns.ac.id ${ }^{2}$ \} \\ Universitas Sebelas Maret, Surakarta, Indonesia ${ }^{1,2}$
}

\begin{abstract}
Researches on language and gender always have the potential to trigger a debate. As a qualitative research implementing a descriptive comparative method with systemic functional discourse analysis and combining Miles \& Huberman's [1] interactive model with Spradley's [2] ethnographic steps, this study explores how male and female film critics review Atomic Blonde movie. Instead of suggesting any universal mapping on how men and women evaluate, this research gives shreds of evidence that power relation and ideological identity have to do with how and why one's language exploitation in evaluating things is different than the others', making this study as a further demonstration of the recent trend in language and gender research: to focus on the context surrounding the text, not on the gender of the text producer.
\end{abstract}

Keywords: Appraisal; Systemic Functional Linguistics; Language and Gender

\section{Introduction}

Studies on language and gender are always debatable. Some argue that there are clear distinctions on how men and women use language, while recent studies demonstrate that universal mapping on language and gender does not actually exist. This debate started with Otto Jesperson in 1922 proposing deficit model based on the essentialist's view; a hiatus of men's and women's languages endorsing the myth of women's inferiority [3]. This model was refuted by Lakoff's [4] dominance theory which is still praised by linguists and experts on gender studies due to its systematic mapping of language use across genders through hedges, question tags, and joke perceptions. In response of the dominance theory, Tannen [5] proposed difference theory providing six contrasts on men's and women's languages: status vs support, independence vs intimacy, advice vs understanding, information vs feeling, order vs proposal, and conflict vs compromise. Her theory implies that women and men have different interpersonal principles instead of different social classes.

Both dominance and difference theory are still considered relevant by linguists and experts on gender studies. Some recent studies still support those principles. Studies done by Baranauskienè \& Admienè [6] and Benham \& Bahar [7] compared the two theories with their exploration on difference and sexism of men's and women's languages in Hemmingway's and Thomas Hardy's fictions respectively. O’Kearny \& Dadds [8] analyzed language differences across genders in adolescent years. Combined with Hallidayan clause complex analysis, Dahunsi [9] found that men are syntactically and semantically complex, while women are syntactically and semantically simplex. 
Aside from those theories, Belcher [10] proposed that it is not the gender, but the discourse, where the text producer participates in, is the factor that differentiates men's and women's languages. This theory suggests the existence of gendered discourse; a competition between masculine and feminine values of rationality and objectivity in a discourse. This idea was demonstrated by Emilia, Moecharam, \& Sylvia [11] showing that classroom is a feminine discourse and Angelini \& Billing [12] drawing a clear gendered discourse differences in different kinds of sport in NBC's Americanized Olympic telecast.

This idea triggered Cameron [13] to open a new discussion on language and gender research. She proposed that a resolute mapping on different use of language based on gender does not exist. She suggested that discourse analysis should be based on the context surrounding the text. This view leads us to a study done by Page [14] trying to find differences between men's and women's evaluative language in childbirth narrative, Fernandes [15] trying to give a mapping on how men and women with aphasia evaluate a story, and Tse \& Hyland [16] diving into how men and women evaluate in academic discourse. Page's [14] study found that different experiences, backgrounds, and positional voices are the factors responsible for language differences. Fernandes' [15] study ended up stating that intimacy plays the most crucial role in narrative elaboration. While Tse and Hyland [16] agreed on the notice of gendered discourse, they also state that the identity of the text producer, social settings, and discourse participation are the motivation behind different uses of language. Although those three studies result in different specific factors of how men's and women's languages are different, they support the same principle: that the difference in language use is based on the context.

Even though all researches representing different ideas on language and gender performed quite sophisticated research, this study finds the arguments on language differences across genders are in a paradoxical situation: how can good researches lead to different results? Moreover, researches supporting different theories mentioned above has at least one representative using the same tool in analysis: appraisal [17].

Thus this study aims to mediate views on language and gender using different method but the same analytical tool, appraisal theory as part of systemic functional linguistics, to test previous researches' credibility. This research chooses movie review genre which is richer in terms of social and cultural issues in which one of them happens to be gender equality, an appropriate issue to be discussed here. In order to scrutinize this issue in linguistic perspective, this research selects review texts on Atomic Blonde movie which supports the movement. Then, this research intends to answer how male and female film critics evaluate the movie and why they evaluate it differently. Answers to those questions will provide an insight into the paradoxical situation where language and gender theories have been positioned.

\section{Literature review}

\subsection{Systemic functional linguistics}

Systemic Functional Linguistics is a theory stating that language is a system of interlocking options reflecting the function of the language used for numerous intentions [18]. Different from Saussure's view on language that divides syntagmatic and paradigmatic sides separately, it puts both sides at the same interacting position [19]. Another crucial aspect of SFL is metafunction suggesting that each utterance employed by a speaker/writer has three 
functions at once. Each function reflects one reality: ideational function reflects physical/biological reality dealing with experiential and logical meaning, interpersonal function reflects social reality, and textual function reflects semiotic reality. Each function can be explored through systems related to the register (field, tenor, and mode) in every linguistic stratum: lexis/phonology, clause, and discourse semantic. One of the systems used by this research as an analytical tool is appraisal.

\subsection{Appraisal}

Appraisal is an interpersonal system in discourse semantic level dealing with the negotiation of the social relation of the text producer through evaluation of things. Appraisal has three interactive domains: attitude dealing with the evaluation of the writer/speaker, engagement dealing with the source of attitude, and graduation dealing with the amplification of attitude [17] \& [20].

There are three kinds of attitude: affect, judgement, and appreciation. Affect deals with humane feelings such as inclination, happiness, security, and satisfaction. Judgement deals with evaluations toward behaviour. It is divided into two: personal judgement concerning normality, capacity, and tenacity and moral judgement concerning veracity and propriety. Appreciation deals with evaluations toward things. It is is divided into three: reaction concerning impact and quality, composition concerning balance and complexity, and valuation [17] \& [20].

Engagement is a system of sourcing attitudes. There are two approaches in analyzing engagement, grammatical and dialogical. While grammatical approach focuses on the linguistic form, dialogical perspective focuses on the alignment of text producers' voices toward their readers'/listeners'. This engagement approach is divided into two: monogloss (based on text producers' own voice) and heterogloss (based on and/or respecting other voices). Heterogloss is divided into two: expand and contract. Expand shows that the writer/speaker tries to play alternative voices around the text without limitation to align her/his voice towards her/his readers'/listeners', while contract is used to limit alternative voices played in the text [17].

Graduation is a system of amplifying attitudes. It is divided into two: force used to grade scalable attitudes and focus used to grade attitudes that are not. In this study, force is analyzed to understand whether an attitude is graded up or down-scaling. Meanwhile, focus is analyzed to understand whether an attitude is sharpened or softened. The limitation on analyzing graduation aims to understand the vagueness of evaluation employed by men and women [4], [17], \& [21]

\section{Research method}

This qualitative research implemented a descriptive comparative method and systemic functional discourse analysis. Sources of data were selected purposively by the use of criterion-based on the register theory allowing this research to get the desirable kinds of data [22]. By combination and modification of Miles and Huberman's [1] interactive model and Spradley's [2] ethnographic steps, this research did four different analyses: domain, taxonomy, componential, and cultural context analysis [23]. Primary data of this research were two movie reviews written by male and female film critics. Motivations behind choosing only 
two rather than many texts to analyze were to demonstrate specific findings as a factor of language differences between men and women and to avoid generalization by respecting the existent of each text producer. Additional analyses on prosody, genre, and ideology were also implemented to achieve more sophisticated results. Secondary data of this research were information and documents related to the background of the male and female movie reviewer.

\section{Findings and discussion}

The result of this study suggests the existence of differences and similarities on how male and female film critics evaluate Atomic Blonde concerning reflection of their tastes and values, their authorial personas, and the vagueness of their voices. These results will be followed by a discussion on each writer's stance on feminism and how they contribute to the paradox of language and gender research.

\subsection{How male and female film critics evaluate Atomic Blonde}

Before discussing appraisal domains, this study will have to consider the role of different forms of appraising items, for they reflect text producers' intentions in the evaluation process. Appraising items can be in the form of epithet, process, attribute, circumstance, and exclamative. In Text 1 written by female reviewer, among 44 attitudes employed, 17 of them are in the form of epithet then followed by effective and middle process. Meanwhile, in Text 2 written by male reviewer, Attitudes employed as epithet appear 33 times, followed by attribute and middle and effective process. This finding suggests that both male and female film critics evaluate most through description imbued to things evaluated [24]. For example:

1. The convoluted plot flashes back to

$\mathrm{D} \quad \mathrm{E}$

ten days earlier [appreciation: composition: -complexity] (T1-DA15)

2. First, it gives Charlize Theron her

D

first legitimate shot at being an

Num E T

action star, [appreciation: +valuation] (T2-DA20)

Another similarity found is that both texts show the same generic structure of review genre [25] \& [26]. Both texts are started by giving context and description of the text, then finished by judging the text. This shows that both of them are doing the same social process, evaluating a text, as the same linguistic community. It is also supported by the fact that both male and female reviewers employ an increasing amount of attitude from judgement, to context and description of the text. However, how they start staging their evaluation across the text makes a difference. The female reviewer starts by elaborating Atomic Blonde's theme with gender equality issue as an urgency to discuss. She later gives descriptions on the main actress (Charlize Theron), the characterization, and the overall theme of the movie generally. Text 2, on the other hand, starts by giving a general evaluation of the director (David Leitch) and the importance of the movie. 
Also, while the total of attitudes employed in Text 1 and Text 2 are 44 and 79 respectively (See Table 1), the total of the clauses in both texts are 59 and 90 respectively. Those numbers support Lakoff's [4] idea that women speak less but challenges her another view stating that women employ more adjectives. This result supports the gendered discourse idea characterizing film criticism as a masculine discourse, for the quantity of one's text and the more freedom one has to deliver his/her emotions show one's dominance [10] \& [16].

\subsection{Values, tastes, and ideas of male and female film critics}

Because the attitude system categorizes the text producer's evaluation of things, detail attitude analysis will be able to reveal how each male and female film critics' criterion of an ideal movie. However, doing that by relying on numbers of attitude is not adequate, for the role of the genre by its mean as social process also takes a huge part. Therefore, it is important to find relations between attitude employed, genre staging, and the gender of the writers which can be seen in Table 1.

Table 1. Relations between attitude, the writers, and genre staging

\begin{tabular}{|c|c|c|c|c|c|c|c|c|c|c|c|c|c|c|c|c|c|c|c|c|c|}
\hline & \multirow{4}{*}{ GSP } & \multicolumn{2}{|c|}{$\begin{array}{l}\text { Aff- } \\
\text { ect }\end{array}$} & \multicolumn{8}{|c|}{ Judgement } & \multicolumn{9}{|c|}{ Appreciation } & \multirow{4}{*}{$\Sigma$} \\
\hline & & \multirow{3}{*}{+} & \multirow{3}{*}{-} & \multicolumn{5}{|c|}{ Social Esteem } & \multicolumn{3}{|c|}{$\begin{array}{c}\text { Social } \\
\text { Sanction } \\
\end{array}$} & \multicolumn{4}{|c|}{ Reaction } & \multicolumn{3}{|c|}{$\begin{array}{c}\text { Composit- } \\
\text { ion }\end{array}$} & \multirow{2}{*}{\multicolumn{2}{|c|}{$\begin{array}{l}\text { Valu- } \\
\text { ation }\end{array}$}} & \\
\hline & & & & \multicolumn{2}{|c|}{ Nor } & \multirow{2}{*}{$\begin{array}{c}\mathrm{Ca} \\
\mathrm{p} \\
+ \\
\end{array}$} & \multicolumn{2}{|c|}{ Ten } & \multirow{2}{*}{$\begin{array}{l}\mathrm{V} \\
\text { er } \\
-\end{array}$} & \multicolumn{2}{|c|}{ Pro } & \multicolumn{2}{|c|}{ Imp } & \multicolumn{2}{|c|}{ Qua } & \multicolumn{2}{|c|}{ Bal } & $\begin{array}{l}\mathrm{C} \\
\mathrm{o} \\
\mathrm{m}\end{array}$ & & & \\
\hline & & & & + & - & & + & - & & + & - & + & - & + & - & + & - & - & + & - & \\
\hline & $\mathrm{C}$ & 1 & & & 1 & 1 & & & & & & 2 & & 1 & & 1 & & & 1 & & 8 \\
\hline 우 & DoT & 4 & 1 & 1 & 3 & 7 & & & 1 & 1 & 1 & 7 & & 7 & 2 & & & 1 & & & 36 \\
\hline & $\mathrm{J}$ & & & & & & & & & & & & & & & & & & & & 0 \\
\hline & $\mathrm{C}$ & & 1 & & & & 4 & & & & & & & & & & & & 7 & 1 & 13 \\
\hline o & DoT & 3 & 7 & & & 7 & 1 & 2 & 1 & 1 & 3 & 13 & 2 & 3 & 2 & & 2 & 2 & 13 & 2 & 64 \\
\hline & $\mathrm{J}$ & & & & & & & & & & & 1 & & & & & & & 1 & & 2 \\
\hline & $\Sigma$ & 8 & 9 & 1 & 4 & 15 & 5 & 2 & 2 & 2 & 4 & 23 & 2 & 11 & 4 & 1 & 2 & 3 & 22 & 3 & $\begin{array}{c}12 \\
3\end{array}$ \\
\hline
\end{tabular}

*GSP: General Structure Potential | C: Context | DoT: Description of Text | J: Judgement | Nor: Normality | Cap: Capacity | Ten; Tenacity | Ver: Veracity | Pro: Propriety | Imp: Impact | Qua: Quality | Bal: Balance | Com: Composition

The transmission of attitudes employed by male and female reviewers throughout the texts with respect to the GSP shows a significant difference. The fact that female reviewer concerns more on the impacts of the movie to its audience and the capacity of the people in the movie production while male reviewer concerns more on the value of the movie reveals that male reviewer concerns more on the abstract aspects of the movie while female reviewer concerns more on the concrete ones. Look at examples below:

1. Theron rivets [appreciation: reaction: +impact] the audience's attention in nearly every frame of David Leitch's film, (T1-DA9)

2. Which is what Atomic Blonde feels like more often than not - the end-game [appreciation: 
+valuation] of modern action cinema, (T2-DA12)

This trend means female film critic argues that ideal films must have concrete results on their audiences' minds and emotions whereas male reviewer argues that ideal movies are those having abstract aesthetic values. This finding challenges Tannen's [5], Page's [14], and Fernandes' [15] studies stating that men are attracted to concrete subjects, while women to abstract things.

\subsection{Authorial personas of male and female film critics}

As system of interpersonal function, the task of appraisal is to explain and argue the relationship between the text producer and the text consumer; to describe how the text producer positions her/himself and her/his hearer(s)/reader(s) in the evaluation process as part of communication. Based on Table 2, with the fact that the male reviewer employs more heteroglossic engagements (34\%) rather than the female one does $(18 \%)$, it can be concluded that Text 2 is more aligning than Text 1 . In a prosody system, though both texts are basically subjective due to their very nature as review texts, Text 1 is more subjective than Text 2 , for heterogloss is a system to achieve objectivity in a text [24].

Table 2. Relations between engagement, the writers, and genre staging

\begin{tabular}{|c|c|c|c|c|c|c|c|c|c|c|c|c|}
\hline & \multirow{5}{*}{ GSP } & \multirow{5}{*}{ Monogloss } & \multicolumn{9}{|c|}{ Heterogloss } & \multirow{5}{*}{$\Sigma$} \\
\hline & & & \multicolumn{6}{|c|}{ Contract } & \multicolumn{3}{|c|}{ Expand } & \\
\hline & & & \multirow{3}{*}{ Pro } & \multicolumn{3}{|c|}{ Proclaim } & \multicolumn{2}{|c|}{ Disclaim } & \multicolumn{2}{|c|}{ Att } & \multirow{3}{*}{ Ent } & \\
\hline & & & & & \multicolumn{2}{|c|}{ Con } & \multirow{2}{*}{ Den } & \multirow{2}{*}{$\mathrm{Cou}$} & \multirow{2}{*}{ Dis } & \multirow{2}{*}{ Ack } & & \\
\hline & & & & Бा10 & Aff & $\mathrm{Ccd}$ & & & & & & \\
\hline & $\mathrm{C}$ & 5 & & & & & & & & 2 & 1 & 8 \\
\hline \multirow[t]{3}{*}{ o } & DoT & 31 & & & & & 1 & 1 & & & 3 & 36 \\
\hline & $\mathrm{J}$ & & & & & & & & & & & 0 \\
\hline & $\mathrm{C}$ & 3 & 2 & & & & 1 & & & & 7 & 13 \\
\hline \multirow[t]{3}{*}{ o } & DoT & 48 & 1 & & 2 & & 1 & 9 & & & 3 & 64 \\
\hline & $\mathrm{J}$ & 1 & & & & & & 1 & & & & 2 \\
\hline & $E$ & 88 & 3 & & 2 & & 3 & 11 & & 2 & 14 & 123 \\
\hline
\end{tabular}

*GSP: General Structure Potential | C: Context | DoT: Description of Text | J: Judgement | Pro: Proclaim | End: Endorse | Con: Concur | Aff: Affirm | Ccd: Concede | Den: Deny | Cou: Counter | Att: Attribute | Dis: Distance | Ack: Acknowledge | Ent: Entertain

Additionally, although Text 1 is less aligning, the female reviewer does try to align her voice towards her readers through entertain; giving chances and spaces for readers' voices to take parts on the ongoing colloquy. She also uses acknowledge; providing other voices as informational fair trader [17, pp.114]. Meanwhile, male reviewer tends to play with his readers' voices through counter system functioning to share an axiological paradigm to his readers; providing medication to persuade them to have the same line of voice [17]. Take a look at examples below: 
1. He's an actor who seemingly [heterogloss: expand: entertain] can't be bad. (T1-DE35)

2. Here, former stunt co-ordinator Leitch is successful, but [heterogloss: contract: disclaim: counter] in a perverse, backwards way. (T2-DE40)

Still, this finding doubts Tannen's [5] two contrasts on intimacy vs independence and compromise vs conflict. It is true that based on the number of attitude which is less than the male reviewer and the heterogloss system she exploits, the female reviewer seems to seek a bit of intimacy with her readers. However, the number of these kinds of engagement is still lower comparing to the number of fully one-sided attitudes which some of them are exploded (see subchapter 4.4). It means that she tends to create herself an independent, brave and open-forconflicts persona, while the male reviewer tries to alter a persuasive one.

\subsection{Language vagueness exploited by male and female film critics}

The basis of language and gender theories is the comparison on the vagueness level of women's and men's language. This argument echoed from Jesperson to Tannen. However, the finding of this study regarding language vagueness suggests that Text 1 is more expressive than Text 2. Even though the majority of both texts' graduation system is force: up-scaling, male reviewer employs more remaining forms of graduation which are considered less expressive and thus increases his language vagueness, while the ratio on the graduations employed by female reviewer reflects a higher number on up-scaling force (See Table 3) and exclamation which is considered explosive attitudes (attitudes employed with the highest scaling of force [20]). Here are some examples:

1. what the hell [force: up-scaling] happened, honeypot [force: up-scaling]? (T1-DG11\&12) 2. Maybe bold isn't quite [focus: sharpen] the right word. (T2-DG02)

Table 3. Relations between graduation, the writers, and genre staging

\begin{tabular}{|c|c|c|c|c|c|c|}
\hline & \multirow{2}{*}{ GSP } & \multicolumn{2}{|c|}{ Force } & \multicolumn{2}{|c|}{ Focus } & \multirow{2}{*}{$\Sigma$} \\
\hline & & Up & Down & Sharpen & Soften & \\
\hline & $\mathrm{C}$ & 6 & 2 & & & 8 \\
\hline \multirow[t]{3}{*}{ 우 } & DoT & 26 & 7 & 2 & 1 & 36 \\
\hline & $\mathrm{J}$ & & & & & 0 \\
\hline & $\mathrm{C}$ & 8 & 1 & 3 & 1 & 13 \\
\hline \multirow[t]{3}{*}{$\hat{\sigma}$} & DoT & 49 & 12 & & 3 & 64 \\
\hline & $\mathrm{J}$ & 2 & & & & 2 \\
\hline & $\Sigma$ & 91 & 22 & 5 & 5 & 123 \\
\hline
\end{tabular}

This finding questions previous theories on language and gender especially Eggins \& Slade [21] and Lakoff [4]. By looking at the contextual aspect of both texts related to the background of the female reviewer: that the female reviewer is a loyal supporter of feminist movement, it is easily understood why her language is more expressive than the male reviewer's, which will be explored more deeply on the following subchapter. 


\subsection{Male and female film critics on feminism}

Atomic Blonde is a bold movie about a female lesbian rogue spy. It tries to endorse gender equality and LGBTQ movement. This research, has been aware of this fact, tries to understand how both of the writers' stances toward it.

The female reviewer, Thelma Adams, as a film critic supporting gender equality throughout her works [27], gives most positive appreciation on Atomic Blonde's impact and quality, praises people around the movie's production with monoglossic engagement and force: up-scaling graduations, ignores the consequences of producing a less aligning and more subjective text, and alters an independence persona. In the genre system, the way she suggests that the movie should have sequels on the judgement stage reflects her hope of more contributions from filmmakers to support the movement. It is very clear to conclude that her stance on the issue is the position of a loyal supporter.

Meanwhile, Barry Hertz, the male reviewer, eventually also supports feminist movement both in Hollywood [28], [29], \& [30] and the Canadian film industry [31]. However, the way he arranges voice-playing in his text keeps him in a more neutral position. Additionally, his evaluation of the movie covers broader aspects than Thelma's: the directing, the visual, the cinematography, the casting, the soundtrack, the storyline, et cetera. This way, he keeps his professional credibility as a review. He produces some arguments on how Atomic Blonde should get more praises than it already had, yet he points out its flaws in a critical way; proving that he tries to alter a two-sided discussion. He employs more aligning and less subjective text and alters a persuasive persona. Still, if his stance is also a loyal supporter of the issue as the same Thelma's, why do they use evaluative language differently?

Both Martin [32] and Fairclough [33] states that language exploitation is a way to achieve power, therefore how one uses language differently than the others must have relation to power. By understanding the situational context through register analysis (appraisal and prosody) and the socio-cultural context through genre, we will be able to draw power relation through ideology analysis [24] \& [32].

Aside from all the praises and supports toward gender and LGBTQ equality brought by Atomic Blonde with no proof of Barry Hertz being in the LGBTQ community, he gains nothing by debating the issue, yet he tries to alter it though two-sided discussion, making him a protagonist-right. On the other hand, because she is a female senior movie critic, with the rise of the gender equality movement, Thelma will eventually gain power. With one-sided arguments, she is considered as antagonist-right; the one holding the issue one-sidedly and gaining power through the debate. Difference ideologies that the male and female reviewers have with respect towards their struggle to achieve power in feminism issue force them to exploit language differently.

\section{Conclusion}

Then it is clear, the motivation behind different uses of language is the relation of the text producer to the power they want to achieve. The female reviewer chooses to focus on the abstract aspects of the text to evaluate, constructs an independent persona for herself, and employs expressive and subjective evaluative language. These results reflect her full struggle to achieve power related to gender equality and LGBTQ issues. On the contrary, the reason why the male reviewer chooses to focus on the concrete aspects of the text to evaluate, alters a 
persuasive persona for himself, and employs neutral and less subjective evaluative language is because his support toward the issues is voluntary; he does not gain any power by doing that.

Different than previous researches analyzing more texts involving more text producers that ended up ruling their existents out by concentrating only to data majority quantitatively, this research demonstrates how and why men's and women's (evaluative) language is different. It is not because of their gender, but the context of the texts they produce which in this case specified by their struggle for power. Surely, power relation is not the main aspect of context behind language use differences across genders. Identity and social setting also play crucial roles. In certain discourses where one gender is the majority, another gender will be oppressed, resulting in a different use of language. Following linguistic behaviorism [34], why one's language use is different from the others' is because s/he is dictated by her/his social environment to do so as part of stimulus reaction, which may be the reason why Lakoff"s [4] and Tannen's [5] ideas are still relevant, they draw a universal mapping on differences of men's and women's language which are actually the effects of the environmental and cultural forces dictating how men's and women's behaviours should be. However, those forces actually are part of the context of the text production. Here, Belcher's [10] gendered discourse also means the context of the text itself. This discussion solves the paradoxical situation of language and gender which supports Cameron's [13] idea stating that universal mapping on language and gender does not exist. Instead, context, in all its forms and aspects, is the force that makes one's language is different from the others'.

\section{References}

[1] Miles and A. M. Huberman, Qualitative Data Analysis: An Expanded Sourcebooks, 2nd ed., London: SAGE Publication, 1994.

[2] J. P. Spradley, The Ethnographic Interview. Long Grove, Illinois: Waveland Press. Inc., 1979.

[3] S. Mulyani, "Language and gender: Toward a critical feminist linguistics," JOLL, 2014, vol. 14 (2), doi: 10.24071/joll.v14i2.376.

[4] R. Lakoff, Language and Women's Place, New York: Harper \& Row, 1975.

[5] D. Tannen, G., Gender and Discourse, London: Oxford University Press, 1996.

[6] R. Baranauskienè and V. Admienè, Gender differences in the language of E. Hemmingway's fiction. $e L A B a, 2012$. [Online] Available: http://gs.elaba.lt/object/elaba:6100252

[7] B. Benham and G. Bahar, "The demonstration of sexism in Thomas Hardy's short stories via appraisal analysis," Journal of Language Teaching and Research, 2013, vol. 4 (2) p. 291-300, doi: 10.4304/j1tr.4.2.291-300.

[8] R. O'Kearney and M. Dadds, "Developmental and gender differences in the language of emotions across the adolescent years," Cognition and Emotion, 2004, vol. 19 (7), pp. 913-938, doi: $10.1080 / 02699930341000356$.

[9] T. N. Dahunsi, "Grammar and gender: A comparative study of the integration and organisation of meaning in selected male and female-authored prose works," IJALEL, 2017, vol. 6 (1), doi: 10.7575/aiac.ijalel.v.6n.1p.275.

[10] D. Belcher, "An argument for non-adversial argumentation: On the relevance of the feminist critique of academic discourse to L2 writing academy pedagogy," Journal of Second Language Writing, 1997, vol. 6 (1), pp. 1-21.

[11] E. Emilia, N. Y. Moecharam, I. L. Syifa, "Gender in EFL classroom: Transitivity analysis in English textbook of Indonesian students," IJAL, 2017, vol. 7 (1), pp. 206-214. DOI: 10.17509/ijal.v7il.6877.

[12] J. R. Angelini, A. C. Billings, "An agenda that sets the frame: Gender, language, and NBC's Americanized Olympic Telecast," JLSP, 2010, vol. 29 (3), pp. 363-385. DOI: 10.1177/0261927X10368831. 
[13] D. Cameron, "Language, Gender, and Sexuality: Current Issues and New Directions." Applied Linguistics, 2005, vol. 26 (4), pp. 482-502, doi: 10.1093/applin/ami027.

[14] R. E. Page, "An analysis of appraisal in childbirth narratives with special consideration of gender and storytelling style," Text, 2003, vol. 23 (2), pp. 211-237, doi: 10.1515/text.2003.009.

[15] A. Fernandes, "Appraisal of Evaluative Language in People with Aphasia's Cinderella Narrative." M. Sc. Thesis, Clinical Linguistics, University of Postdam, Germany, 2011.

[16] P. Tse and K. Hyland, "Discipline and gender: constructing rhetorical identity in book reviews," in Academic Evaluation: Review Genre in University Settings, K. Hyland and G. Diani, Eds., London: Palgrave Macmillan, 2009, ch. 2, sec. 6, pp. 105-119.

[17] J. R. Martin and P. R. R. White, Language of Evaluation: Appraisal in English, New York: Palgrave Macmillan, 2005.

[18] M. A. K. Halliday and C. I. M. I. M. Matthiessen, An Introduction to Functional Grammar, 4th ed., London and New York: Routledge, 2014.

[19] R. Santosa, Semiotika Sosial, Surabaya: Pustaka Pelajar, 2003.

[20] J. R. Martin and D. Rose, Working with Discourse: Meaning Beyond the Clause, Second ed., London: Equinox, 2007.

[21] S. Eggins and D. Slade, Analysing Casual Conversation, London: Cassel, 1997.

[22] Y. S. Lincoln and E. G. Guba, Naturalistic Enquiry, Beverly Hills, California: SAGE Publication, 1985.

[23] R. Santosa, Metode Penelitian Kualitatif Kebahasaan, Surakarta: UNS Press, 2017.

[24] T. Wiratno, Pengantar Ringkas Linguistik Sistemik Fungsional, Yogyakarta: Pustaka Pelajar, 2018.

[25] J. R. Martin and D. Rose, Genre Relations: Mapping Culture, London: Equinox, 2008.

[26] D. Rose, "Genre, Knowledge, and Pedagogy in the Sydney School," in Trends and Traditions in Genre Studies, N. Artamerva and A. Freedman, Eds., Canada: Inkshed, 2015.

[27] T. Adams, "Thelma Adams: Novelist, Critic, Oscar Expert," THELM. http://www.thelmaadams.com/wordpress/ (accessed May 13, 2019).

[28] J. Nadedog, "NBC's 'The Playboy Club' argues it's all about women empowerment," The Hollywood Reporter. http://www.thehollywoodreporter.com/live'feed/nbcs-playboy-club-arguesall-217677/ (accessed May 13, 2019).

[29] N. Wilson, "Pride and Prejudice and Zombies and sexism," Medium. http://medium.com/theestablishment/pride-and-prejudice-and-zombies-and-sexism (accessed May 13, 2019).

[30] B. Hertz, "Review: Captain Marvel's surface-level superhero isn't progress - it's a product," Globe and Mail Review. https://www.theglobeandmail.com/arts/film/reviews/article-review-theostensibly-feminist-forward-captain-marvel-isnt-progress/ (accessed May 13, 2019).

[31] K. Hawkins. "Confronting sexual harassment in Canadian film industry with TFIF," Canadian Women. http://www.canadianwomen.org/blog/confronting-sexual-harassment-in-canadian-filmindustry-with-tfif/ (accessed May 13, 2019).

[32] J. R. Martin, English Text: System and Structure, Amsterdam: John Benjamins, 1992.

[33] N. Fairclough, Critical Discourse Analysis: The Critical Study of Language, London: Routledge, 2013.

[34] G. Graham, "Behaviorism," in Stanford Encyclopedia of Philosophy, E. N. Zalta Ed., Spring 2019 ed., Stanford, California: Metaphysics Research Lab, Stanford University, 2019. 